\title{
BODY SATISFACTION AND SELF-ESTEEM IN PREGNANT WOMEN
}

\author{
L. ANTONIE ${ }^{1}$ M. VINTILA ${ }^{2}$ O.I. TUDOREL T. TTETU $^{3}$ \\ C. C. NANU ${ }^{3}$ M.C. BULARCA ${ }^{4}$
}

\begin{abstract}
The body image of pregnant women has not been addressed in depth in countries such as Romania. The motivation behind the choice of this theme is the conflict that takes place in the life of a pregnant woman, between the social ideals of the feminine aspect and the changes that take place both physically and mentally. The aim of this study is to explore whether self-esteem and certain concepts related to body image (body satisfaction, sexual attractiveness and the importance of body image) differ depending on different relevant factors during pregnancy, such as pregnancy trimester or body weight.
\end{abstract}

Key words: pregnancy, self-esteem, body image, body satisfaction

\section{Introductory Aspects regarding Pregnancy and Body Image}

Pregnancy is described by Finnegan, Mckinstry and Robinson (1982) as a period of psychological maturation, during which old conflicts related to addiction, autonomy, sexuality, aggression and motherhood are resumed, where old solutions are restored. Pregnancy is the ideal time to examine body image because women undergo rapid body changes in a relatively short period of about 40 weeks (Skouteris, Carr, Wertheim, Paxton, and Duncombe, 2005).

Like other stages of development, pregnancy is often a time of crisis, growth and especially change. For pregnant women, it is often important that the pregnancy should be accepted and their body perceived as beautifully and favourably noticed by others (Moore, 1978).

In any context, the concept of image is complex and subject to interpretation. Simply put, the concept of image can be considered a description of an object or person at a certain point in time. In this regard, image can be clear and real, but it can also be ambiguous due to the fact that, the image a person has about itself or another person can be a correct representation of reality, or it can only be the result of one's subjective,

\footnotetext{
1 West University of Timisoara, Romania loredana.antonie98@e-uvt.ro, corresponding author

2 West University of Timisoara, Romania

3 University of Craiova, Romania

4 Transilvania University of Brasov, Romania
} 
incomplete description and perception, that is not necessarily true or real (Coman, 2018a, p.18).

Body image refers to a person's perceptions, feelings, and thoughts about their body and is usually conceptualized as incorporating estimating body size, assessing body attractiveness, and emotions associated with body shape and size (Muth and Cash, 1997). Even more, while communication channels used by mass media have "different public penetration power" (Coman, Rezeanu, Mihalte, and Kiss, 2018, p.41), the image that women have regarding their body can also be influenced by the way mass media presents information about beauty ideals.

Previous studies have shown that body image is one of the key concepts when it comes to the impact it can have on the postnatal period. Women are more likely to report higher levels of suffering in the week following the birth of a healthy and alive child if they have been concerned about the amount of food ingested and the increase in weight during and before pregnancy (Abraham, Taylor, and Conti, 2001).

Although most women seem to adapt during pregnancy to their new body scheme some of them report that they want a smaller stomach, bust and buttocks. Women who express dissatisfaction with their bodies before becoming pregnant tend to show this dissatisfaction throughout pregnancy (Skouteris et al, 2005).

Pregnancy can leave subsequent imprints, women may come to believe that their bodies have become less aesthetically pleasing, in contrast to the period before pregnancy, including birth.

In the context in which a concept is considered "a construction mentally formed by generalizations that result from the attributes of a specific class of things" (Coman, 2013, p.170) body image is a product of socially constructed ideals. Women can perceive pregnancy as a deviation from these ideals, thus protecting body image through a clear delimitation of the concept of "fat" from the concept of pregnancy, being a solid excuse for violation of these ideals (Hodgkinson, Smith and Wittkowski, 2014). This means that professionals: doctors, psychologists, social workers etc. should be very careful with the formal professional language they use (Goian, 2010, 2012) and also some professional skills are requested, which should be acquired by practitioners during their formal intruction for their future profession, as well as through workshops, conferences etc. (Goian, 2004).

Self-esteem has been defined as a global feeling of self-worth, as well as generalized feelings of self-acceptance, kindness, and self-respect (Coopersmith, 1967; Crocker and Major, 1989; Rosenberg, 1965).

Constantin (2004) says that self-esteem refers to the emotional experience and emotions that a person feels when he refers to his own person, more precisely the evaluative component of the self.

One of the most important clues about a woman's feelings about herself as a person is how she describes her body during pregnancy. The physiological symptoms that women experience in the first trimester of pregnancy have a negative impact on their self-image (Davis, 1996).

An intercultural study of a total of 110 pregnant women in Israel and the UK, which aimed to examine the relationship between body mass index and women's body image, self-esteem and eating behaviors during pregnancy, showed a trend towards lower self- 
esteem and a higher prevalence of unhealthy eating habits, but also dissatisfaction with body image among Israeli women.

Moreover, statistical analyzes have shown that the higher the body weight, the greater the dissatisfaction with body image in both countries (Shloim, Hetherington, Rudolf and Feltbower, 2013).

Self-esteem of women who are pregnant and their perception regarding life satisfaction is influenced by many factors. In this regard, one of the factors affecting people's happiness is the quality of their relationships. Thus, people who develop stronger connections with their family, and friends tend to be happier and more satisfied with their life (Coman, 2018b, p.245). In the context of pregnant women, the previously mentioned idea, can mean that women who get along with their family members and build relationships based on trust, honesty and understanding, with them and their friends, during their pregnancy period, can feel appreciated, cared for, thus their self-esteem and satisfaction with their body are more likely to improve.

\section{Methodology}

Participants were approached through social networks. They had to fill in an online questionnaire made in Google Forms which was designed in several sections. The first section included a series of questions related to the collection of demographic data, with different forms of answer.

The next 7 sections were for Body Image for Pregnant Women (Watson, 2017) scale subscales, the penultimate Rosenberg scale and the last section of the Body Understanding Measure for Pregnancy (Kirk and Preston, 2019) scale.

The main eligibility criterion was the age between $18-50$ years. The completion of the questionnaire took about 20 minutes and the respondents gave their consent to participate in completing the questionnaire.

\subsection{Research goals and objectives}

The aim of this study is to explore whether self-esteem and certain concepts related to body image (e.g. body satisfaction, sexual attractiveness and the importance of body image) differ depending on different relevant factors during pregnancy, such as pregnancy trimester or body weight. Thus, starting from the results of the aforementioned studies, the following hypotheses were outlined:

Women who are in their first pregnancy will feel less sexually attractive during pregnancy compared to those who have at least one child.

There is a link between weight gain and body dissatisfaction among pregnant women in the third trimester.

\subsection{Research sample}

A total of 301 women during pregnancy participated in this study. They ranged in age from 19 to 39 years $(M=27.35 ; A S=.258)$. Of which, $22.26 \%$ were in the 1 st trimester of 
pregnancy, $32.56 \%$ in the 2 nd trimester of pregnancy and $45.18 \%$ in the $3 r$ trimester. Regarding the area of origin, $76.41 \%$ of them come from urban areas and the remaining $23.59 \%$ from rural areas.

Data were collected on the marital status of the participants, the data show that $0.66 \%$ are single but date someone, $1.99 \%$ are single, without a partner, $2.33 \%$ are in a relationship without living with partner, $19.27 \%$ are in a relationship, living with a partner, $75.08 \%$ are married and $0.66 \%$ are divorced. A question about the desire to get pregnant was introduced, here the majority of respondents $(97.34 \%, n=293)$ indicated a positive answer, and a negative answer was given by $2.66 \%$ of them.

The number of children was also a topic addressed by self-report questions from the data collection side, more than half of them $(59.47 \%, n=179)$ are at first birth, $35.22 \%$ already have a child, approximately $4 \%$ have two children, $1 \%$ have three children and only one person $(0.33 \%, n=1)$ has 4 children. The participants were asked to report the weight they had before becoming pregnant, the average being $64.08 \mathrm{~kg}$, but also at the current time of pregnancy, with an average weight of $71.86 \mathrm{~kg}$.

\section{Analysis and Discussion}

The statistical analysis of the database corresponding to this study was performed with the help of the SPSS Statistics program variant 20.0 multilingual. To check whether women who are in their first pregnancy will feel less sexually attractive during pregnancy, compared to women who have at least one child, we used the nonparametric Mann-Whitney U test.

Independent sampling was impossible because the assumptions were not met. The results of the Mann-Whitney $U$ test indicate that the sexual attractiveness of pregnant women who are in their first pregnancy (Mean Rank $=139.11$ ) is lower than that of those who have at least one child (Mean Rank $=158.70$ ), differences being statistically significant $\mathrm{U}($ Ncopil $=0=175$, Ncopil $>0=118)=8944,000, Z=-1,946, p=.026$.

Although there are no studies showing similar differences between the number of children and sexual attractiveness during pregnancy, Staruch, Kucharczyk, Zawadzka, Wielgos and Szymusik (2016) showed that about half of those who participated in the study and were pregnant in the third trimester felt less attractive during pregnancy. In fact, similar results were found in the study by Pauleta, Pereira and Graça (2010), where $41.5 \%$ of women felt less sexually attractive.

We used the Pearson correlation to see if there was a link between weight gain and body dissatisfaction among pregnant women in the third trimester. The results indicate that there is a statistically significant and positive link between weight gain and body dissatisfaction of pregnant women in the third trimester $r(128)=.152, p=.043$. The hypothesis was based on common concerns about weight gain during pregnancy (Watson et al. 2016).

The results obtained were contrary to the results obtained by Loth et al (2011), who suggest that regardless of the physical changes that occur with weight gain and changes during pregnancy, pregnant women have significantly higher body satisfaction. 
Shloim, Hetherington, Rudolf, and Feltbower (2013), however, had a similar result, namely an association between weight gain and negative body satisfaction. They found on a group of participants from the UK and Israel that a higher body weight is associated with a higher degree of dissatisfaction with body image in both countries. These results can be true from both points of view.

\section{Conclusions}

It has already been found that pregnancy has an influence on body satisfaction for these women. Body appreciation is a positive dimension of body image, and it refers to the acceptance of the body, as it is, without responding to the pressures of society in relation to the ideal body (Swami et al., 2017).

Further studies could analyze the relationship between body appreciation and breast size among pregnant women (Swami et al., 2020). Moreover, knowing that the connection with nature is associated with a positive well-being and body image (Swami et al., 2019) studies could investigate the effect of nature on the body image of pregnant women.

\section{References}

Abraham, S., Taylor, A., \& Conti, J. (2001). Postnatal depression, eating, exercise, and vomiting before and during pregnancy. International Journal of Eating Disorders, 29(4), 482-487, https://doi.org/10.1002/eat.1046.

Ålgars, M., Santtila, P., Varjonen, M., Witting, K., Johansson, A., Jern, P., \& Sandnabba, N. K. (2009). The Adult Body: How Age, Gender, and Body Mass Index Are Related to Body Image. Journal of Aging and Health, 21(8), 1112-1132, https://doi.org/10.1177/0898264309348023.

Almalik, M. M. A., \& Mosleh, S. M. (2017). Pregnant women: What do they need to know during pregnancy? A descriptive study. Women and Birth, 30(2), 100-106, https://doi.org/10.1016/j.wombi.2016.09.001.

Bondas, T., \& Eriksson, K. (2001). Women's Lived Experiences of Pregnancy: A Tapestry of Joy and Suffering. Qualitative Health Research, 11(6), 824-840, https://doi.org/10.1177/104973201129119415.

Brown, J. D., \& Mankowski, T. A. (1993). Self-esteem, mood, and self-evaluation: Changes in mood and the way you see you. Journal of Personality and Social Psychology, 64(3), 421-430, https://doi.org/10.1037/0022-3514.64.3.421.

Chacko, E. (2020). Pregnancy and Childbirth. International Encyclopedia of Human Geography, 11-17. https://doi.org/10.1016/b978-0-08-102295-5.10416-0.

Coman, C. (2013) Marx Ilussion: Sociological essays about mindsets. Vienna: Osterreichish-Rumanischer Akademischer Verein.

Coman, C. (2018a) Analiza imaginii și influența mass-media [Image Analysis and Mass Media Influence]. Timisoara: The West University of Timisoara Publishing House.

Coman, C. (2018b). Happiness as a resilience resource for the social reproduction of human capital in the private sphere. In R. Veselica, G. Dukic, \& K. Hammes (Eds.), 
Economic and Social Development: Book of Proceedings (pp. 241-247). Varazdin: Varazdin Development and Entrepreneurship Agency.

Coman, C., Rezeanu, C. I., Mihalte, S. I., \& Kiss, R. (2018). Highlighting the image of the local government institutions in mass media based on the results of the content analysis. Juridical Current, 21(1), 39-56.

Constantin T., (2004). Memoria autobiografică: definirea sau redefinirea propriei vieţi. [Autbiographic Memory: Defining and Redefining Your Own Life] lași: European Institute Publishing House.

Coopersmith, S. (1967). The Antecedents of Self-Esteem (1st ed.). San Francisco, California: W. H. Freeman \& Company.

Crocker, J., \& Major, B. (1989). Social stigma and self-esteem: The self-protective properties of stigma. Psychological Review, 96(4), 608-630, https://doi.org/10.1037/0033-295x.96.4.608.

Davis, D. C. (1996). The Discomforts of Pregnancy. Journal of Obstetric. Gynecologic \& Neonatal Nursing, 25(1), 73-81, https://doi.org/10.1111/j.1552-6909.1996.tb02516.x.

Erkaya, R., Karabulutlu, Ö., \& Yeşilçiçek Çalik, K. (2018). The effect of maternal obesity on self-esteem and body image. Saudi Journal of Biological Sciences, 25(6), 1079-1084 https://doi.org/10.1016/j.sjbs.2018.02.003.

Finnegan, P., Mckinstry, E., \& Robinson, G. E. (1982). Denial of Pregnancy and Childbirth. The Canadian Journal of Psychiatry, 27(8), 672-674, https://doi.org/10.1177/070674378202700813.

Goian, C. (2004). Deprinderi in Asistenta Sociala [Social Work Skills]. Bucharest: European Institute Publishing House.

Goian, C. (2010). Zece categorii de inconsecvente semantice prezente in limbajul asistentei sociale din spatula romaneasca [Ten Categories of Semantic Inconsistencies Present in the Language of Social Assistance from the Romanian Spatula] Social Work Review, 1, 79-90.

Goian, C. (2012). Semantic analysis of the dynamics of the social work language applied in Romania. Bucharest: Pro Universitaria.

Hill, B., Skouteris, H., McCabe, M., \& Fuller-Tyszkiewicz, M. (2013). Body Image and Gestational Weight Gain: A Prospective Study. Journal of Midwifery \& Women's Health, 58(2), 189-194, https://doi.org/10.1111/j.1542-2011.2012.00227.x.

Hodgkinson, E. L., Smith, D. M., \& Wittkowski, A. (2014). Women's experiences of their pregnancy and postpartum body image: a systematic review and meta-synthesis. $B M C$ pregnancy and childbirth, 14, 330. https://doi.org/10.1186/1471-2393-14-330.

Inanir, S., Cakmak, B., Nacar, M. C., Guler, A. E., \& Inanir, A. (2015). Body Image Perception and Self-esteem During Pregnancy. International Journal of Womens Health and Reproduction Sciences, 3(4), 196-200, https://doi.org/10.15296/ijwhr.2015.41.

Kazmierczak, M., \& Goodwin, R. (2011). Pregnancy and body image in Poland: Gender roles and self-esteem during the third trimester. Journal of Reproductive and Infant Psychology, 29(4), 334-342. https://doi.org/10.1080/02646838.2011.631179.

Kirk, E., \& Preston, C. (2019). Development and validation of the Body Understanding Measure for Pregnancy Scale (BUMPS) and its role in antenatal attachment. 
Psychological Assessment, 31(9), 1092-1106. http://dx.doi.org/10.1037/pas0000736.

Loth, K. A., Bauer, K. W., Wall, M., Berge, J., \& Neumark-Sztainer, D. (2011). Body satisfaction during pregnancy. Body Image, 8(3), 297-300, https://doi.org/10.1016/j.bodyim.2011.03.002.

Macmullen, N. J. (1991). The Relationship between Self-Esteem and Factors Involved with Self-Esteem Generation in Pregnant Adolescents [Doctoral dissertation]. 2897. Retrieved from: https://ecommons.luc.edu/luc_diss/2897.

Maxson, P., \& Miranda, M. L. (2011). Pregnancy Intention, Demographic Differences, and Psychosocial Health. Journal of Women's Health, 20(8), 1215-1223, https://doi.org/10.1089/jwh.2010.2379.

Moore, D. (1978). The body image in pregnancy. Journal of Nurse-Midwifery, 22(4), 14, https://doi.org/10.1016/0091-2182(78)90080-0.

Muth, J. L., \& Cash, T. F. (1997). Body-Image Attitudes: What Difference Does Gender Make? Journal of Applied Social Psychology, 27(16), 1438-1452, https://doi.org/10.1111/j.1559-1816.1997.tb01607.x.

Obrowski, M. (2016). Normal Pregnancy: A Clinical Review. Academic Journal of Pediatrics \& Neonatology, 1(1), https://doi.org/10.19080/ajpn.2016.01.555554.

Pauleta, J. R., Pereira, N. M., \& Graça, L. M. (2010). Sexuality During Pregnancy. The Journal of Sexual Medicine, 7(1), 136-142. doi:10.1111/j.1743-6109.2009.01538.x.

Rosenberg, M. (1965). Society and the Adolescent Self-Image. Princeton: Princeton University Press.

Sabik, N. J. (2015). Body Image. The Encyclopedia of Adulthood and Aging, 1-5, https://doi.org/10.1002/9781118521373.wbeaa063.

Santos, P. C. (2017, January 23). Physical Activity and Self-Esteem during Pregnancy. Retrieved from https://recipp.ipp.pt/handle/10400.22/9346.

Shloim, N., Hetherington, M. M., Rudolf, M., \& Feltbower, R. G. (2013). Relationship between body mass index and women's body image, self-esteem and eating behaviours in pregnancy: A cross-cultural study. Journal of Health Psychology, 20(4), 413-426, https://doi.org/10.1177/1359105313502568.

Silveira, M. L., Ertel, K. A., Dole, N., \& Chasan-Taber, L. (2015). The role of body image in prenatal and postpartum depression: a critical review of the literature. Archives of Womens Mental Health, 18(3), 409-421, https://doi.org/10.1007/s00737-01.

Skouteris, H., Carr, R., Wertheim, E. H., Paxton, S. J., \& Duncombe, D. (2005). A prospective study of factors that lead to body dissatisfaction during pregnancy. Body Image, 2(4), 347-361, https://doi.org/10.1016/j.bodyim.2005.09.002.

Slade, P. D. (1977). Awareness of body dimensions during pregnancy: an analogue study. Psychological Medicine, 7(02), 245-252, https://doi.org/10.1017/s0033291700029329.

Staruch, M., Kucharczyk, A., Zawadzka, K., Wielgos, M., \& Szymusik, I. (2016). Sexual activity during pregnancy. Neuro endocrinology letters, 37(1), 53-58.

Sugiyama, L. S. (2015). Physical Attractiveness: An Adaptationist Perspective. In D. M. Buss (Ed.), The Handbook of Evolutionary Psychology (pp. 1-68). John Wiley \& Sons.

Swami, V., Tudorel, O., Goian, C., Barron, D., \& Vintila, M. (2017). Factor structure and psychometric properties of a Romanian translation of the Body Appreciation Scale-2. Body Image, 23, 61-68 https://doi.org/10.1016/j.bodyim.2017.08.001. 
Swami, Viren, Mohd. Khatib, N. A., Vidal-Mollón, J., Vintila, M., Barron, D., Goian, C., Mayoral, O., Lin Toh, E. K., Tudorel, O., Vazirani, S., \& Zahari, H. S. (2019). Visits to Natural Environments Improve State Body Appreciation: Evidence from Malaysia, Romania, and Spain. Ecopsychology, 12(1), 24-35. https://doi.org/10.1089/eco.2019.0065.

Swami, Viren, Tran, U. S., Barron, D., Afhami, R., Aimé, A., Almenara, C. A., Alp Dal, N., Amaral, A. C. S., Andrianto, S., Anjum, G., Argyrides, M., Atari, M., Aziz, M., Banai, B., Borowiec, J., Brewis, A., Cakir Kocak, Y., Campos, J. A. D. B., Carmona, C., ... Voracek, M. (2020). The Breast Size Satisfaction Survey (BSSS): Breast size dissatisfaction and its antecedents and outcomes in women from 40 nations. Body Image, 32, 199-217, https://doi.org/10.1016/J.BODYIM.2020.01.006.

Walker, L., Timmerman, G. M., Kim, M., \& Sterling, B. (2002). Relationships Between Body Image and Depressive Symptoms During Postpartum in Ethnically Diverse, Low Income Women. Women \& Health, 36(3), 101-121, https://doi.org/10.1300/j013v36n03_07.

Watson, B., 2016, Developing and validating a measure of body image for pregnant women. DPsych(Clin) thesis. School of Psychology: Deakin University. Retrieved from http://dro.deakin.edu.au/view/DU:3010116

Watson, B., Broadbent, J., Skouteris, H., \& Fuller-Tyszkiewicz, M. (2016). A qualitative exploration of body image experiences of women progressing through pregnancy. Women and Birth, 29(1), 72-79. https://doi.org/10.1016/j.wombi.2015.08.007. 